\title{
HEADTEACHERS' ADMINISTRATIVE DUTIES AND TEACHER JOB PERFORMANCE IN PUBLIC JUNIOR HIGH SCHOOLS AT AGONA SWEDRU, GHANA
}

\author{
Albert Dzidzor Amenu', \\ Kweku Esia-Donkoh ${ }^{2 i}$, \\ Afia Asantewa Osei ${ }^{3}$ \\ ${ }^{1}$ Ghana Cocoa Board, \\ Agona Swedru, \\ Ghana \\ 2Department of Educational Foundations, \\ University of Education, Winneba, \\ Ghana \\ ${ }^{3}$ University of Cape Coast, \\ Cape Coast, \\ Ghana
}

\begin{abstract}
:
The study investigated the relationship between headteachers' administrative duties and teacher job performance in public Junior High Schools at Agona Swedru in the Agona West Municipality of the Central Region of Ghana. This study adopted the quantitative correlational research design. Teachers in all public Junior High Schools at Agona Swedru in the Central Region of Ghana, formed the target population, while the accessible population covered all teachers in public Junior High Schools at Agona Swedru who had spent at least a year in their respective schools. Simple random sampling technique was used to obtain 70 teachers whose responses to items in closed-ended questionnaire were used for the analysis for this study. One significant finding was that the headteachers performed all the administrative duties outlined in the study even though they predominantly performed the duty of school-community relationship. Generally, the performance of the teachers was very good with discipline and punctuality recording the highest mean. Again, a strong positive and significant relationship between administrative duties of headteachers and teacher job performance was established. Among the recommendations is that the Education Directorate in the Agona West Municipality should organise in-service training for headteachers of public Junior High Schools at Agona Swedru to enable them to improve on their administrative duties to influence teacher job performance.
\end{abstract}

Keywords: headteachers, administrative duties, teacher, job performance

'Correspondence: email ke donkoh@yahoo.com 


\section{Introduction}

Education, which is a human right of every individual of school-going age, is widely acknowledged as the cornerstone of the progress of nations (Appiah \& Esia-Donkoh, 2018; Onyesum \& Ashibogwu, 2013). Given this, the government of Ghana has committed itself to some international protocols to provide basic education for all Ghanaian children. Some of these protocols are Millennium Development Goals (MDGs) and Sustainable Development Goals (SDGs). The implementation of these protocols, no doubt, has resulted in increased access and participation, especially at the primary and junior high school levels of Ghana's education system.

These schools are administered in most cases by experienced teachers who serve as leaders. In Ghana, such leaders are called headteachers and are mandated to see to the effective administration of their various schools (Baffour-Awuah, 2011; Gregory, 2010). This implies that the role of the headteacher in the practical education delivery at the primary and junior high school levels is crucial and significant. Thus, headteachers are essential in the effective administration of schools by performing specific duties (Kimutai \& Kosgei, 2012). It could be inferred from this assertion that headteachers are responsible for all administrative activities of schools, and more significantly, to ensure that teachers are effective in performing their tasks and offer quality basic education to the learners.

The preceding suggests that the success or failure of basic schools in Ghana is greatly dependent on headteachers who are responsible for all activities carried out in the school. In this wise, they are expected to perform their administrative duties with the needed skills to achieve set targets. The indication is that to attain educational and school objectives, certain specific duties must be performed by headteachers of basic schools in Ghana. These include planning, financial administration, record keeping and management, ensuring effective school-community relationship, staff and pupil personnel services, improving and maintaining physical facilities and educational resources, as well as teachers' instructional improvement and appraisal (Ghana Education Service, 2010a, 2010b; Ojo \& Olaniyan, 2008).

In basic schools in Ghana, headteachers set goals with the help and assistance of teachers, School Management Committee, Parent Teacher Association, the Ghana Education Service within the District, Municipality or Metropolis of the school, and other stakeholders and standards to be achieved. They also ensure that policies, processes, and procedures are followed to the latter. In so doing, headteachers, through the performance of their duties, help supervise, monitor, inspect, assess, and evaluate the progress of teachers and learners to help strategise for the future. Again, headteachers encourage teacher professional development through the organisation of school-based in-service training programmes. They also motivate and support teachers by providing the necessary resources and enabling an environment to enhance instructional delivery and learning, safety for teachers and learners, and guidance and counselling services for both teachers and learners. It must be noted that even though headteachers are held responsible for performing their duties, it does not imply they perform all these duties 
alone. They can perform these duties through assignments and delegation of work to other teachers in the school.

Based on these duties performed by headteachers, it has been argued (Okon, 2004; Esia-Donkoh, 2019) that ensuring and maintaining quality and standards in education delivery largely depends on how headteachers effectively undertake their administrative responsibilities. Essential administrative qualities expected of headteachers in performing their responsibilities, among others, include professional training, leadership, interpersonal relationship, organisational ability, communication skills, good physical and mental health, and personality (Sidhu, 2011).

It is believed that teacher job performance is another essential and critical factor in achieving school and educational goals. This idea is why Gultom (2012) emphasised that teacher job performance is important because teachers are responsible for students' success and student outcomes. Kane (2010) also opined that teacher and their performance play a crucial role in ensuring the quality of knowledge imparted to students. Logically, it is deduced that the high performance of teachers results in the good academic achievement of learners and qualitative improvement of the standard of life. On the other hand, poor teacher performance is likely to result in low academic performance. This implies that the extent to which teachers perform their duties is and should be a matter of concern to education stakeholders. Hence, as part of their administrative duties, headteachers of public Junior High Schools, including those at Agona Swedru, Ghana, are to see that teachers perform their duties as required.

The twenty-first century has seen an increased acknowledgement of the significance of effective leadership, management and administration for the successful operation of educational institutions (Bush, 2011). Therefore, maintaining quality and standards in education largely depends on how heads of schools effectively carry out their leadership and administrative responsibilities (Ibukun, Oyewole \& Abe, 2011). This presupposes that the importance of headteachers in ensuring quality and effective basic schools in Ghana cannot be overemphasised. As administrators and leaders, headteachers have a significant influence on the success of basic schools by influencing all aspects of the school's functions with their behaviours and personal characteristics. As such, they are expected to perform a wide range of duties to ensure that effective teaching and learning occur in their schools to achieve the set objectives and goals (Ghana Education Service, 2010a; Ghana Education Service, 2010b).

\section{Statement of the Problem}

In Ghana, the academic performance of pupils, especially those in Junior High Schools, has become a matter of concern to all education stakeholders in recent decades. For instance, the Ministry of Education (MOE) (2013) observed that there had been an increased poor teacher and student performances in recent times. This observation by MOE, no doubt, is an issue of concern to stakeholders of education in the nation as a whole. Deductively, stakeholders of basic education at Agona Swedru are equally 
concerned with the poor results obtained by learners in the Basic Education Certificate Examination (BECE). The question likely to be asked is, "are the poor task performance of teachers observed by the MOE, Ghana Education Service (GES), and other stakeholders, especially those at Agona Swedru, influenced by the administrative duties of headteachers in public basic schools?"

Various studies have been undertaken by different scholars and researchers on the relationship between headteachers' administrative practices and teacher job performance. For instance, Brown and Owusu (2014) and Nnamdi and Nwite (2014) found a positive relationship between the headteachers' administrative practices and teacher job performance. The same may not be said of the relationship between headteachers' administrative practices and teacher job performance in public Junior High Schools at Agona Swedru since such a study has not been conducted in the town. Blasé and Blasé (2000) have also argued that there is no consensus on the influence of headteachers' administrative duties on teacher job performance. Thus, this study was relevant in public Junior High Schools at Agona Swedru, Ghana, to contribute to the arguments and discussions on the relationship between headteachers' administrative duties and teacher job performance.

\section{Significance of the Study}

The findings of this study may augment the existing store of knowledge on the subject and serve as the basis for further research to explore headteachers' administrative duties for prudent administration and management of public basic schools at Agona Swedru for the overall improvement in teacher job performance. The findings of this study may also help headteachers in public basic schools at Agona Swedru, Ghana, to be aware of their administrative duties and how they relate to the job performance of their teachers. This would guide headteachers to either strengthen their administrative duties or modify them when it becomes necessary. Educational planners and policymakers at the Agona West Municipal Directorate of GES would make use of the findings of this study to develop strategies to improve administrative duties of headteachers and job performance of teachers in public basic schools in general, and the Junior High School in particular to ensure quality and effective basic education delivery.

\section{Research Questions}

This study was guided by the following research questions:

1) What administrative duty is predominantly performed by headteachers of public junior high schools Agona Swedru?

2) What is the level of teacher job performance in public Junior High Schools at Agona Swedru?

3) What relationship exists between headteachers' administrative duties and teacher job performance in public Junior High Schools at Agona Swedru? 


\section{Literature Review}

Headteachers of basic schools in Ghana ensure adequate supervision of instruction. This administrative duty embraces all the planned, implemented, supervised, and evaluated activities in the school. According to Esia-Donkoh (2019), such activities aim to develop the students' cognitive, psychomotor, and affective domains. Supervision of instruction aims at the full development of the teachers into the most professionally efficient persons they are capable of becoming. Thus, supervision enhances understanding between teachers and supervisors on effective instructional processes through a collaborative effort. Akube, as cited in Nzewi (2014), opined that supervisory activities consist of seeking the factors related to teachers and learners' growth and improving teachers' skills by employing effective supervisory techniques. Aspects of teaching and learning evaluated include lesson planning, knowledge of the subject, lesson delivery and classroom management, work output, attitude to work, punctuality and attendance, personality and social traits, human relations and communication. Evaluation of teaching and learning helps to measure students' ability and to diagnose their weaknesses. It also helps to measure the school's activities to determine if the developmental and educational needs of the school are being met.

Nzeli (2013) explained that the staff personnel duty directs the headteacher to carry out a staff needs assessment such as inducting and orienting new teachers, organising staff training and development, appraising and recommending staff for promotions as well as providing a conducive climate at the school for all members. By this function, the headteacher is expected to attract, select, motivate, supervise, develop and maintain teaching and non-teaching staff. The headteacher needs to identify and indicate the staff needs of the school, as well as the specific type of staff needed to meet the needs.

In Ghana, teaching and non-teaching staff are posted to public basic schools by Ghana Education Service. Hence, such school heads have no choice but to accept the staff posted to the schools. The headteacher has to see that new staff members are appropriately oriented into the school system and its general way of doing things. The headteacher is to involve the staff in developing and operating the regular and proper personnel policies, including schedules of staff assignments, creation of good working conditions, the establishment of clear communication channels, and provision of staff development through regular in-service training and seminars, and encourage staff to join and attend subject association workshops.

Educational institutions are social organisations that succeed in practical interrelationships between them and their relevant publics, hence, the essence of effective school-community relationships. Ogunu (2001) maintained that the school-community relationship is a series of planned activities and media through which the school seeks to know about the community and involve them in planning and evaluating school policies and progress. Oboegbulem (2004) argued that the school is established to address the needs and aspirations of society. Hence, no school can operate in a vacuum without the 
society or community it serves. Proper interaction between the school and the community enables the community to determine ways of providing the human and material resources required to implement the school programme.

Nwankwo (2010) stressed that the community could aid the school in procuring some of the facilities needed to make the school child-friendly, and a thorough understanding of the needs and problems of the community will help the school adjust meaningfully to the demands and expectations of the society. Again, public awareness of the school's philosophy, problems, and needs will set a good climate for them to support the school. For an effective school-community relationship, the headteacher needs to know the community in which the school is situated, take an active part in the community's development, and encourage the staff to do the same. He or she ought to encourage and facilitate community participation in the school's activities and explain the activities of the school to the community.

Headteachers' administrative duty of pupil personnel service seeks to encourage and enhance regular classroom instructions. This duty of the headteacher is essential because it involves the selection, orientation, placement, as well as guidance and counselling of students, which constitute an essential aspect of educational administration (Esia-Donkoh, 2019; Ojo \& Olaniyan, 2008). In Ghana, headteachers of public basic schools ensure that pupils are adequately motivated and allowed to learn. As such, this function requires the headteacher to organise teachers to see to the welfare of students. Headteachers are also to promote guidance services by ensuring that material assistance is given to the guidance co-ordinators to work in co-operation with teachers to achieve a smooth running of guidance programmes in schools. Headteachers are to ensure the school institutes procedures for the orientation of pupils, especially the new ones on the school rules and regulations, discipline, moral and civic issues, good interpersonal relations, selection of subjects, and career guidance.

Headteachers are to see to it that schools are secure and safe for pupils. As such, they are to ensure a friendly, physically safe, emotionally secure and physically enabling school environment. Headteachers are to collaborate with local health workers to organise health fairs to enable learners and the whole community to learn and practice good health, especially on COVID-19, Hepatitis, and HIV/AIDS issues. The headteacher needs to ensure that student inventories such as records on continuous assessment and conduct of students are kept, policies and procedures for dealing with pupils' misconduct established, and pupils' disciplinary cases handled with the co-operation of the School Management Committee and Parent Association. The headteacher must develop, coordinate, and encourage extra-curricular activities such as games and sports to enhance learners' mental and physical health needs.

Another essential administrative duty of headteachers is to see the improvement and maintenance of the school's physical facilities and educational resources. Onwurah (2004) alluded that physical facilities' management involves planning to meet the need of educational institutions. Hence, there is no question over the supervision of infrastructural facilities, which are considered an essential duty every school head must 
perform. Physical facilities of the school, which are mainly provided by the government, communities, corporate bodies, philanthropists and non-governmental organisations, include school buildings (school plant), school grounds, laboratories, equipment, libraries, workshops, school buses, and instructional equipment needed for effective teaching and learning. Esia-Donkoh (2019) reiterated that headteachers of public basic schools in Ghana are expected to make their school environment child-friendly to ensure that the learners are physically safe, emotionally secure and psychologically enabling.

To avoid unnecessary intrusion, heads of public basic schools are to see to the school site's fencing, walling, or hedging to make it secure and safe. Leaking school roofs and broken-down tables and chairs must be repaired. The heads are also to maintain a conducive school environment by planting trees as windbreaks and providing shade, promoting floral rock beautification of the school compound to raise their aesthetic value and prevent erosion. Recreational facilities and space for sports, games, physical education and the use of gender disability-friendly playing equipment must be provided. There is also the need for toilets and urinals to be provided for pupils and teachers. It must be emphasised that without good buildings and a clean environment, the students' comfort will be affected, which can hinder their ability to learn. It is, therefore, the responsibility of headteachers to manage these facilities by taking good care of them and ensuring that they are fully utilised.

Baduson-Lincoln (2018) studied the perception of headteachers and teachers in public basic schools in Sebrepor Education Circuit in the Greater Accra Region of Ghana. The results revealed that different headteachers practised different administrative functions in public basic schools in the Circuit. The findings showed that the headteachers predominantly performed the administrative duty of pupil personnel service as compared to instructional, supervisory duties, staff personnel service, schoolcommunity relationship, and management of physical facilities and educational materials. Collectively, the headteachers were found to perform their administrative duties at a high level. Similarly, Kirui and Osman (2012) established from their study that headteachers undertake different administrative duties to achieve the school's goals, and generally, the goals of education.

Many researchers opine that teachers perform a critical role in educating learners, which makes the job performance of teachers essential to the attainment of educational goals and, consequently, the effectiveness and success of the school. For instance, Ikegbusi \& Iheanacho, 2016) argued that teachers' performance is imaginable, the most significant factor that impacts education processes. This stresses the assertion that teachers are considered the pivot of any educational system (Olorunfemi, as cited in Appiah \& Esia-Donkoh, 2018). Motowidlo, Martin and Crook (2013, p. 42) explained job performance as "an individual output in terms of quality and quantity expected from every employee in a particular job'. This shows that individual performance is determined by motivation and the will and ability to do the job most of the time. Adejumobi and Ojikutu (2013) also stressed that teacher job performance could be measured through observing teacher activities in actual classroom teaching performance, including lesson preparation, 
teacher commitment, extra-curricular, supervision, effective leadership, motivation and morale.

Researchers on teacher job performance have undertaken some studies, and these have established different levels of job performance. Adeyemi's (2011) study in Nigerian revealed a moderate level of teacher job performance in senior secondary schools. Usop et al. (2013) concluded that the teachers of the Division of Cotabato City displayed a high level of performance, discharged their responsibilities and exhibited appropriate behaviours that resulted in the realisation of the objectives of the schools. Other studies (Amin et al., 2013; Ghanney et al., 2017) have established that teachers' level of job performance as expressed by themselves was high. Similarly, some studies (Achana, 2019; Appiah \& Esia-Donkoh, 2018; Ibrahim \& Dahie, 2016) have revealed excellent and good teacher job performance in schools. However, Selamat et al. (2013) found out that the levels of job performance among secondary school teachers in the Klang District in Malaysia were low and that none of the teachers showed a high level of job performance.

Findings from various studies (Brown \& Owusu, 2014; Ehtesham, Muhammad \& Muhammad, 2011; Hinners, 2009; Nnamdi \& Nwite, 2014; Onuma, 2015) have established a positive relationship between the headteacher's administrative practices and teacher performance. Although there is a shred of evidence that headteachers management practices are linked with teacher job performance, other studies (Adebola, 2006; Castller, 2010) have revealed that the relationship between these two variables has not been consistent over time. Nevertheless, Brown and Owusu (2014) argued that administrative or management practices of headteachers could improve the quality of decisions, increase the decision's acceptance rate and provide avenues for learning new skills, inspire staff, instil commitment and teamwork, build trust among staff, and increase overall school effectiveness. Ezieke (2015) shared this view by asserting that management practices of headteachers stand out as one of the most critical variables for teacher job performance that assists in the realisation of school and educational goals.

The quality and strength of staff available have been considered one of the critical factors that contribute immensely to the success of the education sector (UNESCO, 2006). Given the increased enrolment in Ghanaian basic schools as a result of the implementation of policies such as Free Compulsory Basic Education (FCUBE), EFA, MDGs and interventions like Capitation Grant and School Feeding Programme, the demand for classroom teachers and high expectations from teachers concerning their task performance has also increased (Appiah \& Esia-Donkoh, 2018).

\section{Methodology}

This study was quantitative, underpinned by the positivists' research philosophy, and employed the correlation research design to investigate the relationship between headteachers' administrative duties and teacher job performance in public Junior High Schools at Agona Swedru, Ghana. Teachers in public Junior High Schools were the respondents for this study. The simple random technique was used to obtain seventy (70) 
teachers who had served in their respective schools for at least a year. A structured questionnaire made up of three sections (demographic, leadership style, and job performance sections) used to collect quantitative data from the respondents was reliable after analysing pre-test data. Alpha Co-efficient of 0.83 was obtained for leadership style and 0.81 for teacher job performance.

\section{Results and Findings}

In analysing the data obtained, frequency, percentages, mean, standard deviation and the Pearson correlation coefficient were used.

\subsection{Analysis of Demographic Characteristics}

The results of the analysis of the demographic data are shown in Table 1.

Table 1: Demographic Characteristics of Respondents

\begin{tabular}{|l|c|c|}
\hline Variables & Frequency & Percentage (\%) \\
\hline Sex & 39 & 55.7 \\
\hline Male & 31 & 44.3 \\
\hline Female & 70 & 100.0 \\
\hline Total & \multicolumn{2}{|l|}{} \\
\hline Age & 20 & 28.6 \\
\hline Less than 30 & 27 & 38.6 \\
\hline 30 to 39 & 18 & 25.7 \\
\hline 40 to 49 & 5 & 7.1 \\
\hline 50 and above & 70 & 100.0 \\
\hline Total & \multicolumn{2}{|l|}{} \\
\hline Academic Qualification & 20 & 28.6 \\
\hline Diploma & 35 & 50.0 \\
\hline Bachelor's Degree & 15 & 21.4 \\
\hline Master's Degree & 70 & 100.0 \\
\hline Total & \multicolumn{2}{|l|}{} \\
\hline Experience & 25 & 35.7 \\
\hline 1-4 years & 22 & 31.4 \\
\hline 5-8 years & 20 & 28.6 \\
\hline 9-12 years & 3 & 4.3 \\
\hline 13 years and above & 70 & 100.0 \\
\hline Total &
\end{tabular}

Source: Survey data (2020).

The analysis of the demographic data showed that 70 respondents, made up of $39(55.7 \%)$ males and $31(44.3 \%)$ females, were involved in the study. Twenty $(28.6 \%)$ of the respondents had ages below 30 years, while 27 (38.6\%) were between 30 and 39 years. Eighteen (25.7\%) respondents had their ages between 40 and 49 years, and the remaining $5(7.1 \%)$ were 50 years or more. The distribution of the respondents on academic qualification showed that half of the respondents had bachelor's degrees $(n=35,50.0 \%)$ as 
compared to those who had diplomas $(\mathrm{n}=20,28.6 \%)$ and master's degrees $(\mathrm{n}=15,21.4 \%)$. With work experience, the data revealed that $25(35.7 \%)$ of the respondents had been teaching in their school between one and four years, 22(31.4\%) had been teaching between five and eight years, 20(28.6\%) had been teaching between nine and twelve years, while three $(4.3 \%)$ had been teaching for 13 or more years.

\subsection{Administrative Duty Mostly Performed by Headteachers}

The first research question sought to determine the administrative duty dominantly performed by headteachers of public Junior High Schools at Agona Swedru. The results of the analysis are presented in Table 2 .

Table 2: Headteachers' Administrative Duties

\begin{tabular}{|l|c|c|c|}
\hline Administrative duties & $\mathbf{N}$ & Mean & Std. Deviation \\
\hline Supervision of instruction & 70 & 3.1 & 1.06 \\
\hline Staff personnel service & 70 & 3.2 & 1.02 \\
\hline School-community relationship & 70 & 3.3 & 1.24 \\
\hline Improving and maintaining physical facilities and educational resources & 70 & 3.1 & 1.15 \\
\hline Pupil personnel service & 70 & 3.2 & 1.14 \\
\hline Overall administrative duties & 70 & 3.2 & 1.12 \\
\hline
\end{tabular}

Source: Survey data (2020).

Data in Table 2 revealed that different headteachers perform different administrative duties in public junior high schools at Agona Swedru. However, the results showed that headteachers predominantly performed the duty of school-community relationship $(\mathrm{M}=3.3, \mathrm{SD}=1.24)$ as compared to staff personnel service $(\mathrm{M}=3.2, \mathrm{SD}=1.02)$, pupil personnel service $(\mathrm{M}=3.2, \mathrm{SD}=1.14)$, supervision of instruction $(\mathrm{M}=3.1, \mathrm{SD}=1.06)$, and improving and maintaining physical facilities and educational resources $(\mathrm{M}=3.1$, $\mathrm{SD}=1.15)$. Collectively, all the headteachers' administrative duties yielded a mean of 3.2 $(\mathrm{SD}=1.12)$. Even though the administrative duty of the school-community relationship was dominant among the headteachers, the data imply that the headteachers practised all the administrative duties in their schools.

\subsection{Teacher Job Performance}

Research Question 2 sought to determine the level of teacher job performance as outlined in the study. The extent to which teachers performed their job was determined based on the criteria in Table 3.

Table 3: Guideline for Interpreting Job Performance

\begin{tabular}{|l|c|c|}
\hline Scale & Range (Mean Score) & Level of Job Performance \\
\hline 1 & $0.01-1.00$ & Poor \\
\hline 2 & $1.01-2.00$ & Fair \\
\hline 3 & $2.01-3.00$ & Good \\
\hline 4 & $3.01-4.00$ & Very good \\
\hline 5 & $4.01-5.00$ & Excellent \\
\hline
\end{tabular}

Source: Adapted from Underwood (2004). 
As shown in Table 3, the level of job performance ranged from poor to excellent based on the 5-point Likert scale used. Mean scores ranging from 0.01 to 1.00 is classified as poor; 1.01 to 2.00 is described as fair; 2.01 to 3.00 is classified as good; 3.01 to 4.00 is labelled as very good; and 4.01 to 5.00 is considered as excellent. The results on teachers' job performance are presented in Table 4.

Table 4: Mean and Standard Deviation for Job Performance

\begin{tabular}{|l|c|c|}
\hline Variables & Mean & Std. Deviation \\
\hline Instructional Skills & 3.7 & 0.93 \\
\hline Classroom Management Skills & 3.7 & 1.01 \\
\hline Discipline and Punctuality & 3.8 & 0.97 \\
\hline Interpersonal Skills & 3.7 & 0.98 \\
\hline Overall Job Performance & 3.7 & 0.97 \\
\hline
\end{tabular}

Source: Survey Data, 2020.

A comparison of the results in Table 4 with the guideline provided in Table 3, the teachers' level of performance on instructional skills $(\mathrm{M}=3.7, \mathrm{SD}=0.93)$, classroom management skills $(\mathrm{M}=3.7, \mathrm{SD}=1.01)$, discipline and punctuality $(\mathrm{M}=3.8, \mathrm{SD}=0.97)$, interpersonal skills $(\mathrm{M}=3.7, \mathrm{SD}=0.98)$ as well as the overall job performance $(\mathrm{M}=3.7$, $\mathrm{SD}=0.97$ ) were rated as very good. The results showed that teachers rated highest on discipline and punctuality.

\subsection{Relationship between Headteachers' Administrative Duties and Teacher Job Performance}

The purpose of the third research question was to examine the relationship between the administrative duties of headteachers and teacher job performance. To achieve the purpose of the research question, statements that measured administrative duties of headteachers and teacher job performance were presented to respondents to answer. These statements were measured on a five-point Likert scale; $1=$ strongly disagree (SD), 2=disagree (D), 3=neutral (N), 4=agree (A), and 5= strongly agree (SA).

The statistical tool used in analysing it was Pearson Product Moment Correlation. The research question was answered with a 0.05 alpha level, and the analysis summary is presented in Table 5 .

Table 5: Relationship between Headteachers'

Administrative Duties and Teacher Job Performance

\begin{tabular}{|l|l|c|c|}
\hline \multicolumn{2}{|c|}{} & Administrative Duties & Job Performance \\
\hline \multirow{4}{*}{ Administrative Duties } & Pearson Correlation & 1 & $0.830^{*}$ \\
\cline { 2 - 4 } & Sig. (2-tailed) & & 0.026 \\
\cline { 2 - 4 } & $\mathrm{N}$ & 70 & 70 \\
\hline \multirow{3}{*}{ Job Performance } & Pearson Correlation & $0.830^{*}$ & 1 \\
\cline { 2 - 4 } & Sig. (2-tailed) & 0.026 & 70 \\
\cline { 2 - 4 } & $\mathrm{N}$ & 70 & \\
\hline${ }^{*}$ Correlation is significant at the 0.05 level (2-tailed). & \multicolumn{2}{|l}{} \\
\hline
\end{tabular}

Source: Survey Data, 2020. 
Kothari (2004) suggested that coefficients of less than 1.0 but equal to 0.5 imply a strong relationship, coefficients greater than 0.3 but less than 0.5 indicate a moderate relationship, while coefficients less than 0.3 show a weak relationship. Based on Kothari's (2004) suggestion, the results in Table 5 show a strong positive relationship $(r=0.830 ; \mathrm{N}$ $=70 ; \mathrm{p}<0.05)$ between headteachers' administrative duties and teacher job performance. The coefficient of determination $\left(0.830^{2}\right)$ indicated approximately $68.9 \%$ shared variance between headteachers' administrative duties and teacher job performance in public Junior High Schools at Agona Swedru, Ghana. Thus, an improvement in the administrative duties of headteachers will lead to an improvement in teacher job performance and vice versa.

\section{Discussion}

The results of the first research question established that headteachers of public Junior High Schools perform various administrative duties at Agona Swedru. This finding substantiates earlier studies (Baduson-Lincoln, 2018; Kirui \& Osman, 2012) that headteachers perform diverse administrative duties to attain school and educational goals.

The second research question investigated the extent to which teachers in public junior highs schools at Agona Swedru performed their job. It was revealed from the results that the teachers' level of job performance was perfect for all the scales (instructional skills, classroom management skills, discipline and punctuality, interpersonal skills) of job performance outlined in this study, as well as the overall job performance. This notwithstanding, it was found out that the teachers had the highest job performance in discipline and punctuality. This finding is in line with Appiah and Esia-Donkoh (2018), who established that teachers' job performance in public basic schools in Mankessim Education Circuit was very good. Again, it substantiates the findings of Amin et al. (2013), Ghunney et al. (2017) and Usop et al. (2013) that teachers' level of job performance as expressed by themselves was high. However, the finding of this study departs from that of Selamat et al. (2013), which established low levels of job performance among secondary school teachers in Klang District in Malaysia, and that none of the teachers showed a high level of job performance. Again, it contradicts Adeyemi's (2011) finding, which revealed moderate levels of teacher job performance.

The study also sought to establish the relationship between the administrative duties of headteachers and job performance among teachers in public junior high schools at Agona Swedru, Ghana. The results showed a strong positive relationship between administrative duties of headteachers and teacher job performance. This finding corroborates that of earlier studies such as those conducted by Brown and Owusu (2014), Nnamdi and Nwite (2014), and Ehtesham, Muhammad and Muhammad (2011). These studies revealed a positive relationship between the headteachers' administrative practices and teacher job performance. 


\section{Conclusions}

The study has produced proof to validate that administrative duties of headteachers of public junior high schools at Agona Swedru relate to teachers' job performance. This implies that if these administrative duties are performed effectively by the headteachers, the teachers' job performance would be enhanced. Therefore, it is essential for headteachers of public junior high schools at Agona Swedru to ensure that their administrative duties are effectively undertaken to improve the level of the job performance of their teachers. It has also been established from the results that the teachers' job performance was very good with discipline and punctuality recording the highest rating. This suggests that the teachers could put in extra effort to improve the other subscales of teacher job performance when headteachers of public Junior High Schools at Agona Swedru perform their administrative duties very well. Thus, it is concluded that headteachers could enhance the job performance of their teachers when they (headteachers) focus on the adequate performance of their administrative duties.

\section{Recommendations}

In light of the findings, this study recommended that the Ghana Education Service Directorate in the Agona West Municipality periodically organise in-service training for headteachers of public Junior High Schools to improve their administrative duties to enhance their administrative duties the attainment of school and educational goals. The Directorate should organise regular workshops for teachers to improve their performance, especially on instructional skills, classroom management skills, interpersonal skills, and discipline and punctuality to ensure instructional outcomes. It is also recommended that the Directorate of the Ghana Education Service in the Agona West Municipality should ensure the provision of relevant administrative support for headteachers. This could be achieved through regular visits to the public Junior High Schools to advise and encourage headteachers to perform their duties as expected of them. The Education Directorate in the Agona West Municipality should see to it that the needed instructional and other educational resources are provided to the public Junior High Schools to enhance the performance of the teachers' work.

\section{Conflict of Interest Statement}

The authors declare no conflicts of interests.

\section{About the Authors}

Albert Dzidzor Amenu is currently a Principal Technical Officer at the Ghana Cocoa Board at Agona Swedru, Ghana. He holds a Master of Education degree in Educational Administration and Management. His research interest include issues on administration and management, supervision and staff development. 
Kweku Esia-Donkoh, is currently a Senior Lecturer in Educational Administration at the Department of Educational Foundations, Faculty of Educational Studies, University of Education, Winneba, Ghana. He has also served as a Faculty member in the Department of Basic Education, and the Department of Psychology and Education, all in the same University. He has about twenty-four years teaching experience at different levels of education in Ghana. His research interest include issues on school leadership, administration and management, school organisation and culture, teacher professional development, pedagogy, and supervision of instruction. He has over thirty articles in peer reviewed and indexed journals. He is also a peer reviewer for International Journal of Basic Education Research and Policy. He is currently a PhD Candidate in Educational Leadership at the University of Cape Coast, Ghana.

Afia Asantewa Osei is currently an Assistant College Secretary at the Presbyterian College of Education, Akropong, Ghana. She has about seventeen years teaching experience in both pre-tertiary and tertiary institutions in Ghana. Her research interest include educational leadership and staff development. She has three publications. She is currently a PhD Candidate in Educational Leadership at the University of Cape Coast, Ghana.

\section{References}

Achana, L. (2019). Relationship between headteachers' leadership styles and teachers' job performance in public and private schools in the Odumase Amanfrom Education Circuit. Unpublished Master of Education Dissertation, University of Education, Winneba, Ghana.

Adebola, O. J. (2006). School administration and supervision. In J. B. Babalola, A. O. Ayeni, S. O. Adedeji, A. A. Suleiman \& M. O. Arikewuyo (Eds.), Educational management: Thoughts and practice. Codal Publications.

Adejumobi, F. T., \& Ojikutu, R. K. (2013). School climate and teacher job performance in Lagos State, Nigeria. Discourse Journal of Educational Research, 1(2), 26-36. http://citeseerx.ist.psu.edu/viewdoc/download?doi=10.1.1.1067.4207\&rep=pdf

Adeyemi, T. O. (2011). Teachers' job satisfaction and job performance in secondary schools in Ekiti State, Nigeria. International Journal of Afro-Asian Studies, 2(2), 41-51. https://www.researchgate.net/publication/267969574

Brown, M., \& Owusu, A. A. (2014). Influence of head teachers' management styles on teacher motivation in selected Senior High Schools in the Sunyani Municipality of Ghana. International Journal of Learning, Teaching and Educational Research, 4(1), 6175.

Amin, M., Shah, R., Ayaz, M., \& Atta, M. A. (2013). Teachers' job performance at secondary level in Khyber Pakhyunkhwa, Pakistan. Gomal University Journal of Research, 29(2). $\quad$ http://www.gomal.pk/GUJR/PDF/Dec-2013/13Rahmat\%20Ullah\%20Shah.pdf 
Appiah, A. K., \& Esia-Donkoh, K. (2018). Teacher job performance: The role of headteachers' supervisory styles in public basic schools in Mankessim circuit. Research Journal of Education, 4(12), 212-220. https://doi.org/10.32861/rje.412.212.220

Baduson-Lincoln, I. (2018). Administrative duties of headteachers: Perception of headteachers and teachers in public basic schools in Sebrepor education circuit. Unpublished Master of Education Dissertation, University of Education, Winneba, Ghana.

Baffour-Awuah, P. (2011). Supervision of instructions in public primary schools in Ghana: Teachers and head teachers' perspectives. Doctoral thesis, Murdoch University. http://www.researchrepository.murdoch.edu.au/8483/2/02Whole.pdf.

Blase, J., \& Blase, J. (2000). Effective instructional leadership: Teachers perspectives on how principals promote teaching and learning in schools. Journal of Educational Administration, 38(2), 130-141. https://doi.org/10.1108/09578230010320082

Brown, M. \& Owusu, A. (2014). Influence of head teachers' management styles on teacher motivation in selected Senior High Schools in the Sunyani Municipality of Ghana. International Journal of Learning, Teaching and Educational Research, 4(1), 61-75. https://www.researchgate.net/publication/264232206

Bush, T. (2011). Theories of educational leadership and management (4th ed.). SAGE.

Castller, A. O. (2010). Management support and the teachers. Sorrence Publisher.

Ehtesham, U. M., Muhammad, T. M. \& Muhammad, S. A. (2011). Relationship between Organizational Culture and Performance Management Practices: A Case of University in Pakistan. Journal of Competitiveness, 11(4), 78-86. https://www.cjournal.cz/files/77.pdf

Esia-Donkoh, K. (2019). Administration and management of schools. Edsam.

Ezieke, C. E. (2015). Correlates of management practices of primary school headteachers in promoting child-friendly School environments In South-East Nigeria. (Unpublished PhD Thesis, University of Nigeria, Nsukkain). http://www.unn.edu.ng/publications/files/17894.pdf

Ghana Education Service (2010a). Headteachers' handbook (2nd ed.). Ministry of Education.

Ghana Education Service (2010b). School management committee resource handbook (2nd ed.). Ministry of Education.

Ghanney, R. A., Antwi, T., \& Ali, H. (2017). School culture and teacher job performance: A comparative analysis of the perception of teaching staff in private and public basic schools in Ga South Municipality. British Journal of Education, 5(9), 108-121. http://www.eajournals.org

Gregory, C. F. (2010). Institutional supervision: A descriptive study focusing on the observation and evaluation of teachers in cyber schools, Pennsylvania. Doctoral Dissertation, Indiana University, USA. https://eric.ed.gov/?id=ED523215

Gultom, S. (2012). Teacher job performance review. Skripsi.

Hinners, N. W. (2009). Management by wandering around. NASA's Mars Exploration Programme Analysis Group, University of Colorado Aerospace Engineering Sciences Department. http://www.pmhut.com/ 
Ibrahim, A. A., \& Dahie, A. M. (2016). The impact of training and development on employee performance in Mogadishu Somalia. International Journal of Multidisciplinary Research, 2(10), 45-50. https://www.academia.edu/29277078.pdf

Ibukun, W. O., Oyewole, B. K., \& Abe, T. O. (2011). Personality characteristics and principal leadership effectiveness in Ekiti state, Nigeria. International Journal of $\begin{array}{lll}\text { Leadership } \quad \text { Studies, 247-262. } & \end{array}$ https://www.regent.edu/acad/global/publications/ijls/new/vol6iss2/5 jm.pdf

Ikegbusi, N. G. \& Iheanacho, R. C. (2016). Factors militating against effective administration of secondary schools in Anambra state. World Journal of Educational Research, 3(1), 1-14. https://core.ac.uk/download/pdf/268085527.pdf

Kane, T. J. (2010). What does certification tell us about teacher effectiveness? Evidence from New York City. National Bureau of Economic Research.

Kimutai, T., \& Kosgei, F. (2012). Influence of school head's direct supervision on teachers. A Journal of Education, 45, 88-90. https://www.semanticscholar.org/paper/618871d52e3a6bd887eeebefab6fee1551b $\underline{\mathrm{b} 2888}$

Kirui, L. M. \& Osman, J. W. (2012). Role of the headteacher in academic achievement in Secondary Schools in Vihiga District Kenya. Journal of Social Sciences, 1(3), 84-92. https://maxwellsci.com/print/crjss/(3)84-92.pdf

Kothari, C. R. (2004). Research methodology, research and techniques. New Age International Publishers.

Ministry of Education (2013). Education strategic plan 2010 to 2020. Ministry of Education, Ghana.

Motowidlo, S. J., Martin, M. P., \& Crook, A. E. (2013). Relations between personality, knowledge, and behaviour in professional service encounters. Journal of Applied Social Psychology, 49 (4), 1851-1861. https://doi.org/10.1111/jasp.12137

Nnamdi, E. S. \& Nwite, O. (2013). Human resource management skills required by school principals in public secondary schools in Rivers State. Journal of the Nigeria Academy of Education (JONAED), 10(1), 17-33. https://files.eric.ed.gov/fulltext/ED585939.pdf

Nwankwo, T. C. (2010). Good school-community relationship as tool for effective school administration in Anambra State public schools. A Paper Presented at all Nigerian Conference of Principals of Secondary School [ANCOPSS] Anambra State Branch, August 72009.

Nwezi, S. (2014). Administration of human resources. Tech and Pro Publishers.

Nzeli, K. A. (2013). Challenges faced by female headteachers in the administration of secondary schools: A case of Kangundo district in Machakos county, Kenya, (Unpublished MED Thesis; Department of Educational Administration, Policy and Curriculum Studies, Kenyatta University). https://irlibrary.ku.ac.ke/bitstream/handle/123456789/7023

Oboegbulem, A. I. (2004). Staff personnel administration. In Mgbodile T.O (Ed.). Fundamental in Educational Administration and Planning. Magnet Computer Services. 
Ogunu, M. (2001). Introduction to educational administration. Mabogun Publishers.

Ojo, L. B., \& Olaniyan, D. A. (2008). Leadership roles of school administrators and challenges ahead in post-primary institutions in Nigeria. European Journal of Scientific Research, 24(2),

172-178. https://medwelljournals.com/abstract/?doi=sscience.2008.406.410

Okon, J. E. (2004). Understanding administrative behaviour in educational organisations. Ultimate Index.

Onuma, N. (2015). Principals' management support practices for enhancing teachers' performance in secondary schools in Nigeria. Journal of Emerging Trends in Educational Research and Policy Studies (JETERAPS), 6(1), 11-17. https://www.eajournals.org

Onwurah, C. U. (2004). School plant administration. In Mgbodile, T.O. (Ed), Fundamental in educational administration and planning. Magnet Computer Services.

Onyesom, M. and Ashibogwu, N. K. (2013). Towards quality assurance in business education in Nigeria, Constraints and control. Asian Journal of Business Management, 5(3), 306-12. https://pdfs.semanticscholar.org/5bca/f52fb7500669c59c25085a20bbe1117dc7a4.p df

Selamat, N., Samsu, N. Z., \& Kamalu, N. S. (2013). The impact of organisational climate on teachers' job performance. Educational Research, 2(1), 71-82. https://doi.org/10.5838/erej.2013.21.06

Sidhu R, (2011). Supporting refugee students in schools; What Constitutes inclusive education. International Journal of Inclusive Education, University of Queensland. http://dx.doi.org/10.1080/13603110903560085

Underwood, J. (2004). What is your corporate IQ? Dearborn Trade Publishing.

UNESCO (2006). Synergies between formal and non-formal education: An overview of good practices. UNESCO/UIE.

Usop, A. M., Askandar, K., Langguyuan-Kadtong, M. L., \& Usop, D. A. (2013). Work performance and job satisfaction among teachers. International Journal of Humanities and Social Science, 3(5), 245-252. http://www.ijhssnet.com/journals/Vol 3 No 5 March 2013/25.pdf 
Albert Dzidzor Amenu, Kweku Esia-Donkoh, Afia Asantewa Osei

HEADTEACHERS' ADMINISTRATIVE DUTIES AND TEACHER JOB PERFORMANCE

IN PUBLIC JUNIOR HIGH SCHOOLS AT AGONA SWEDRU, GHANA

Creative Commons licensing terms

Author(s) will retain the copyright of their published articles agreeing that a Creative Commons Attribution 4.0 International License (CC BY 4.0) terms will be applied to their work. Under the terms of this license, no permission is required from the author(s) or publisher for members of the community to copy, distribute, transmit or adapt the article content, providing a proper, prominent and unambiguous attribution to the authors in a manner that makes clear that the materials are being reused under permission of a Creative Commons License. Views, opinions and conclusions expressed in this research article are views, opinions and conclusions of the author(s). Open Access Publishing Group and European Journal of Education Studies shall not be responsible or answerable for any loss, damage or liability caused in relation to/arising out of conflicts of interest, copyright violations and inappropriate or inaccurate use of any kind content related or integrated into the research work. All the published works are meeting the Open Access Publishing requirements and can be freely accessed, shared, modified, distributed and used in educational, commercial and non-commercial purposes under a Creative Commons Attribution 4.0 International License (CC BY 4.0). 